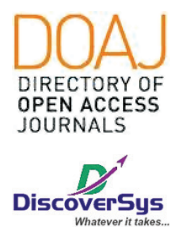

Published by DiscoverSys

\title{
Temuan ultrasonografi pada kecurigaan klinis tumor payudara ganas di RSUP Sanglah periode januari - desember 2015
}

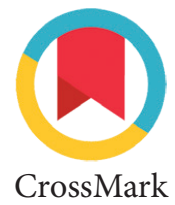

\author{
I Kadek Riyandi Pranadiva Mardana, ${ }^{1 *}$ Elysanti Dwi Martadiani, ${ }^{2}$ \\ Firman Parulian Sitanggang ${ }^{2}$
}

\section{ABSTRACT}

Background: cancer is the second leading cause of death in Indonesia, whereas $70 \%$ of patients have themselves examined at an advanced stage. One of the methodes to do breast cancer screening is by ultrasound examination to see each characteristic in several aspects (form, size, ecogenicity, components) found in the clinical suspicion of malignant cases.

Methods: This study was conducted to see the importance of the role of ultrasonography in knowing the characteristics of malignant breast tumors in Sanglah General Hospital. This study was a cross-sectional descriptive (retrospective) at Sanglah General Hospital. Ultrasound examination data collection had been done from medical record of breast tumor patients (total sampling from January to December 2015). Data analysis study used digital data processing programs and presented in crosstabulating tables.
Results: Total of 52 subjects showed 51 patients with normal characteristics of cutaneous tissue (98.1\%), normal ecoparenkim in 47 patients (90.4\%), 34 with no abnormalities characteristics of nodules/masses/cysts (65.4\%), 46 with normal ecogeneity characteristics (88.5\%), regular lesion characteristics of shape/edge in 47 patients (90.4\%), 37 with no abnormalities characteristics of the lesion (71.2\%), 49 patients (94.2\%) did not show any abnormalities characteristics of papillary calcification and retraction, 49 patients without abnormalities characteristics of papilla retraction, 47 patients $(90.4 \%$ ) without abnormalities characteristics of axilla glands.

Conclusions: Ultrasonography characteristics result as the screening tool for malignant breast tumor in this study is able to asess some general features founded in malignant breast tumor cases.

Keywords: breast tumors, ultrasound, characteristics

Cite This Article: Mardana, I.K.R.P., Martadiani, E.D., Sitanggang, F.P. 2020. Temuan ultrasonografi pada kecurigaan klinis tumor payudara ganas di RSUP Sanglah periode januari - desember 2015. Intisari Sains Medis 11(1): 388-392. D0I: 10.15562/ism.v11i1.552

Latar Belakang: Kanker payudara merupakan keganasan penyebab mortalitas kedua tersering di Indonesia, dimana 70\% dari penderita memeriksakan dirinya pada stadium lanjut. Salah satu cara skrining kanker payudara yaitu dengan pemeriksaan ultrasonografi. Setiap karakteristik hasil ultrasonografi memiliki tujuan penting untuk mengetahui bentuk, ukuran, ekogenitas, dan komponen lain yang dijumpai pada kecurigaan klinis tumor payudara ganas.

Metode: Penelitian ini bertujuan melihat pentingnya peranan ultrasonografi dalam mengetahui karakteristik tumor payudara ganas di RSUP Sanglah. Penelitian ini merupakan penelitian deskriptif cross-sectional retrospektif di RSUP Sanglah. Prosedur penelitian berupa pengumpulan data pemeriksaan ultrasonograsi dari data rekam medis pasien tumor payudara (total sampling dari bulan Januari-Desember 2015). Analisis data menggunakan program pengolah data digital dan menyajikannya dalam tabel crosstabulating.
Hasil: Total dari 52 orang subjek, 51 orang (98,1\%) menunjukkan hasil normal pada karakteristik jaringan kutis, 47 orang $(90,4 \%)$ dengan hasil normal pada karakteristik ekoparenkim, dari karakteristik nodul/ massa/kista 34 orang pasien $(65,4 \%)$ tidak tampak adanya kelainan, dari karakteristik ekogenitas 46 orang pasien (88,5\%) menunjukan hasil normal, dari karakteristik bentuk/tepi lesi 47 orang pasien (90,4\%) dengan bentuk/tepi lesi yang reguler, dari karakteristik batas lesi tidak ditemukan adanya kelainan pada 37 orang pasien (71,2\%), dari karakteristik kalsifikasi dan retraksi papilla masing-masing 49 orang pasien (94,2\%) tidak tampak adanya kelainan, dari karakteristik retraksi papilla 49 orang pasien tidak ditemukan adanya kelainan, dari karakteristik kelenjar aksila 47 orang pasien $(90,4 \%)$ tidak ditemukan adanya kelainan.

Simpulan: Karakteristik gambaran ultrasonografi sebagai skrining kasus tumor payudara ganas dalam penelitian ini mampu menilai beberapa temuan yang umum terjadi pada pasien tumor payudara ganas.
Udayana

riyandi_pradana@rocketmail.com
Kata kunci: Tumor payudara ganas, ultrasonografi, karakteristik

Cite Pasal Ini: Mardana, I.K.R.P., Martadiani, E.D., Sitanggang, F.P. 2020. Temuan ultrasonografi pada kecurigaan klinis tumor payudara ganas di RSUP Sanglah periode januari - desember 2015. Intisari Sains Medis 11(1): 388-392. D0I: 10.15562/ism.v11i1.552 


\section{PENDAHULUAN}

Cedera pada tulang belakang adalah dislokasi atau fraktur dari satu atau lebih tulang belakang yang diakibatkan oleh trauma sehingga menyebabkan terjadinya edema, kontusi dan sebagainya. Penderita cedera pada tulang belakang dapat mengalami kehilangan fungsi motorik, sensasi, aktivitas refleks dan kehilangan kontrol terhadap pencernaan dan ginjal, dapat mengalami perubahan body image, penampilan peran dan konsep diri. ${ }^{1}$ Fraktur atau dislokasi yang terjadi pada bagian mana pun dari tulang belakang disebut dengan cedera pada tulang belakang. Semakin tinggi terjadi dislokasi ataupun fraktur, semakin besar pula efek disfungsinya dan insiden dari cedera pada tulang belakang ini terus meningkat.

Kanker payudara mejadi salah satu kanker yang ditakuti oleh banyak kalangan wanita baik remaja maupun dewasa. Lebih dari 40.000 orang meninggal akibat kanker payudara setiap tahunnya. Menurut data WHO tahun 2005, sebanyak 506.000 wanita meninggal oleh karena kanker payudara. ${ }^{1}$

Di Indonesia, angka kejadian kanker payudara menempati urutan kedua setelah kanker serviks. Sekitar 10 dari 100.000 penduduk terkena kanker payudara dan $70 \%$ dari penderita memeriksakan dirinya pada keadaan stadium lanjut. Tingkat insiden yang tinggi berada pada negara-negara maju, dibandingkan dengan di negara berkembang yang tingkat insidennya cukup rendah namun angkanya semakin meningkat. ${ }^{1}$

Terdapat beberapa penelitian yang menunjukkan cara mendeteksi kanker payudara yaitu skrining yang efektif. Alat skrining yang digunakan adalah mamografi, namun masih banyak perdebatan terkait keuntungan mamografi untuk perempuan usia 40-49 tahun. Ultrasonografi sangat berguna untuk membedakan lesi solid dan kistik. Gambaran ultrasonografi tergantung pada ukuran, jumlah, lokasi, dan sifat dari lesi. ${ }^{2}$

Ultrasonografi tidak memiliki efek samping radiasi, sehingga pemeriksaan ini lebih dipilih dibandingkan mamografi. ${ }^{3}$ Semakin meningkatnya insiden kanker payudara, tingkat mortalitas akibat kanker payudara, dan terbatasnya data terkait gambaran ultrasonografi pada kanker payudara, maka penulis ingin melakukan penelitian yang berjudul "Temuan Ultrasonografi Pada Kecurigaan Klinis Tumor Payudara Ganas Periode Januari 2015-Desember 2015".

\section{METODE}

Penelitian ini adalah penelitian deskriptif dengan metode cross-sectional. Penelitian ini bersifat retrospektif dengan menggunakan data sekunder yang diperoleh dari rekam medis. Penelitian ini dilakukan selama lima bulan (Agustus-Desember 2016) di Rumah Sakit Umum Pusat Sanglah, Denpasar. Populasi terjangkau dari penelitian ini adalah semua pasien dengan kecurigaan klinis tumor payudara ganas dengan pemeriksaan ultrasonografi yang tercatat dalam rekam medis di Instalasi Radiologi RSUP Sanglah, Denpasar. Sampel penelitian adalah populasi terjangkau dengan kecurigaaan klinis tumor payudara ganas di Instalasi Radiologi RSUP Sanglah tahun 2015.

Teknik pengumpulan sampel yang digunakan adalah total sampling dimana semua pasien dengan kecurigaan klinis tumor payudara ganas memenuhi kriteria inklusi diikutkan dalam penelitian sepanjang masih dalam rentang waktu pengumpulan data. Input dan pengolahan data hasil penelitian diolah dengan menggunakan program pengolah data digital dan data tersebut dikelompokkan menurut tipe lesi, dan temuan lainnya yang selanjutnya akan disajikan dalam tabel crosstabulating.

Penelitian ini telah mendapat ethical clearance dari Komite Etik RSUP Sanglah. Data nomor rekam medis pasien diperoleh dari Bagian Rekam Medis RSUP Sanglah. Ekstraksi data rekam medis pasien dilakukan di ruang rekam medis RSUP Sanglah.

\section{HASIL}

Berdasarkan rentang waktu penelitian yang dilaksanakan dari bulan Agustus-Desember 2016, jumlah pasien dengan kecurigaan klinis tumor payudara ganas yang diketahui dengan ultrasonografi di RSUP Sanglah dan diikutkan dalam penelitian ini berjumlah 52 orang. Setelah data di analisis secara statistik deskriptif, dari total 52 sampel, 34 orang $(65,4 \%)$ diantaranya tidak disebutkan dalam rekam medis karena sampel telah dilakukan masektomi, 13 orang $(25,0 \%)$ tampak adanya massa solid, dan 5 orang $(9,6 \%)$ ditemukan gambaran kistik (Tabel 1).

Jika dilihat dari karakteristik gambaran ekoparenkim pada temuan ultrasonografi tumor payudara ganas, 47 orang $(90,4 \%)$ tidak ditemukan adanya kelainan, dan 5 orang $(9,6 \%)$ sisanya ditemukan adanya gambaran ekoparenkim yang tidak normal (Tabel 2).

Karakteristik selanjutnya yang ditinjau dalam penelitian ini adalah karakteristik gambaran jaringan kutis pada temuan ultrasonografi, dari 52 sampel, 51 orang $(98,1 \%)$ diantaranya tidak ditemukan kelainan pada jaringan kutis, dan 1 orang $(1,9 \%)$ memiliki gambaran jaringan kutis yang tidak normal pada pemeriksaan ultrasonografi (Tabel 3). 
Tabel 1 Karakteristik Gambaran Nodul/ Massa/ Kista pada Temuan Ultrasonografi Tumor Payudara Ganas

\begin{tabular}{lcc}
\hline Nodul/ Massa/ Kista & Frekuensi & Persentase \\
\hline Tidak disebutkan pada Rekam Medis & 34 & $65,4 \%$ \\
Solid & 13 & $25,0 \%$ \\
Kistik & 5 & $9,6 \%$ \\
Total & 52 & $100 \%$ \\
\hline
\end{tabular}

Tabel 2 Karakteristik Gambaran Ekoparenkim pada Temuan Ultrasonografi Tumor Payudara Ganas

\begin{tabular}{lcc}
\hline Ekoparenkim & Frekuensi & Persentase \\
\hline Normal & 47 & $90,4 \%$ \\
Tidak Normal & 5 & $9,6 \%$ \\
Total & 52 & $100 \%$ \\
\hline
\end{tabular}

Tabel 3 Distribusi Karakteristik Gambaran Jaringan Kutis pada Temuan Ultrasonografi Tumor Payudara Ganas

\begin{tabular}{lcc}
\hline Jaringan Kutis & Frekuensi & Persentase \\
\hline Normal & 51 & $98,1 \%$ \\
Tidak Normal & 1 & $1,9 \%$ \\
Total & 52 & $100 \%$ \\
\hline
\end{tabular}

Tabel 4 Karakteristik Gambaran Ekogenitas Lesi pada Temuan Ultrasonografi Tumor Payudara Ganas

\begin{tabular}{lcc}
\hline Ekogenitas Lesi & Frekuensi & Persentase \\
\hline Isoechoic & 46 & $88,5 \%$ \\
Hipoechoic & 6 & $11,5 \%$ \\
Total & 52 & $100 \%$ \\
\hline
\end{tabular}

Tabel 5 Karakteristik Gambaran Bentuk/ Tepi Lesi pada Temuan Ultrasonografi Tumor Payudara Ganas

\begin{tabular}{lcc}
\hline Bentuk/Tepi Lesi & Frekuensi & Persentase \\
\hline Tidak disebutkan pada Rekam Medis & 34 & $65,4 \%$ \\
Reguler & 13 & $25,0 \%$ \\
Ireguler & 5 & $9,6 \%$ \\
Total & 52 & $100 \%$ \\
\hline
\end{tabular}

Tabel 6 Karakteristik Gambaran Batas Lesi pada Temuan Ultrasonografi Tumor Payudara Ganas

\begin{tabular}{lcc}
\hline Batas Lesi & Frekuensi & Persentase \\
\hline Tidak disebutkan pada Rekam Medis & 34 & $65,4 \%$ \\
Tegas & 13 & $25,0 \%$ \\
Tidak Tegas & 5 & $9,6 \%$ \\
Total & 52 & $100 \%$ \\
\hline
\end{tabular}

Jika dilihat dari karakteristik gambaran ekogenitasnya, dari 52 sampel, 46 orang diantaranya memiliki karakteristik ekogenitas payudara isoechoic, dan 6 orang $(11,5 \%)$ ditemukan memiliki gambaran ekogenitas hipoechoic (Tabel 4).

Jika dilihat dari karakteristik gambaran bentuk/ tepi lesi pada temuan ultrasonografi tumor payudara ganas, 34 orang $(65,4 \%)$ diantaranya tidak disebutkan dalam rekam medis karena sampel telah dilakukan masektomi, 13 orang $(25,0 \%)$ memiliki gambaran tepi lesi regular, dan 5 orang $(9,6 \%)$ ditemukan gambaran tepi lesi ireguler (Tabel 5).

Karakteristik lain yang ditinjau dalam penelitian ini adalah terkait gambaran batas lesi dari temuan ultrasonografi tumor payudara ganas. Dari 52 sampel, diketahui karakteristik batas lesi payudara yang diantaranya tidak disebutkan dalam rekam medis karena sampel telah dilakukan masektomi sebanyak 34 orang (65.4\%) sedangkan jumlah pasien dengan batas lesi payudara tegas sebanyak 13 orang $(25.0 \%)$, dan dengan batas lesi payudara tidak tegas sebanyak 5 orang (9.6\%) (Tabel 6).

Karakteristik selanjutnya yang juga dinilai dalam penelitian ini yaitu terkait temuan gambaran kalsfikasi pada ultrasonografi. 49 orang $(94,2 \%)$ diantaranya tidak disebutkan dalam rekam medis karena sampel telah dilakukan masektomi dan 3 orang $(5,8 \%)$ sisanya ditemukan gambaran kalsifikasi (Tabel 7).

Adanya temuan retraksi papilla pada ultrasonografi juga dinilai dalam penelitian ini. Jumlah pasien yang tampak gambaran retraksi papilla sebanyak 3 orang $(5,8 \%)$ dan 49 orang $(94,2 \%)$ diantaranya tidak disebutkan dalam rekam medis karena sampel telah dilakukan masektomi (Tabel 8).

Karakteristik terakhir yang ditinjau dalam penelitian ini adalah adanya gambaran kelenjar aksila pada temuan ultrasonografi tumor payudara ganas. Tidak tampak adanya gambaran kelainan kelenjar aksila pada 47 orang $(90,4 \%)$, dan 5 orang $(9,6 \%)$ tampak adanya kelainan gambaran kelenjar aksila pada ultrasonografi (Tabel 9).

\section{DISKUSI}

Kanker payudara merupakan kasus kedua tersering yang dapat menimbulkan kematian pada wanita setelah kanker serviks. Sekitar 60\% kasus kanker payudara terjadi pada wanita usia diatas 60 tahun. ${ }^{4}$ Gejala awal kanker payudara biasanya berupa benjolan yang dirasakan berbeda dari jaringan payudara di sekitarnya, tidak nyeri, dan lebih sering memiliki tepi ireguler. ${ }^{5}$ Selain dari anamnesis dan pemeriksaan fisik, diagnosis pasti dari tumor atau 
Tabel 7 Karakteristik Gambaran Kalsifikasi pada Temuan Ultrasonografi Tumor Payudara Ganas

\begin{tabular}{lcc}
\hline Kalsifikasi & Frekuensi & Persentase \\
\hline Tidak disebutkan pada Rekam Medis & 49 & $94,2 \%$ \\
Tampak & 3 & $5,8 \%$ \\
Total & 52 & $100 \%$ \\
\hline
\end{tabular}

Tabel 8 Karakteristik Gambaran Retraksi Papilla pada Temuan Ultrasonografi Tumor Payudara Ganas

\begin{tabular}{lcc}
\hline Retraksi Papilla & Frekuensi & Persentase \\
\hline Tidak disebutkan pada Rekam Medis & 49 & $94,2 \%$ \\
Tampak & 3 & $5,8 \%$ \\
Total & 52 & $100 \%$ \\
\hline
\end{tabular}

Tabel 9 Karakteristik Gambaran Kelenjar Aksila pada Temuan Ultrasonografi Tumor Payudara Ganas

\begin{tabular}{lcc}
\hline Kelenjar Aksila & Frekuensi & Persentase \\
\hline Normal & 47 & $90,4 \%$ \\
Tidak Normal & 5 & $9,6 \%$ \\
Total & 52 & $100 \%$ \\
\hline
\end{tabular}

kanker payudara dapat diketahui dari pemeriksaan tambahan, salah satunya seperti ultrasonografi.

Ultrasonografi atau lebih dikenal sebagai USG, merupakan suatu pemeriksaan yang sering digunakan untuk skrining tumor atau kanker payudara. USG dapat menilai adanya benjolan, tepi atau bentuk lesi, adanya kalsifikasi, membedakan lesi solid dan kistik, serta apakah terdapat peningkatan ekogenitas atau tidak. ${ }^{6}$

Beberapa data hasil penelitian ini tidak sejalan dengan penelitian sebelumnya. Pada data karakteristik gambaran jaringan kutis, penelitian ini menyebutkan bahwa sebagian besar sampel memiliki gambaran jaringan kutis normal pada tumor payudara ganas, berbeda dengan hasil penelitian yang dikemukakan oleh Ramli $\mathrm{dkk}^{7}$ yang menyebutkan pada umumnya pada kasus tumor payudara ganas memiliki gambaran jaringan kutis yang tidak normal.

Karakteristik gambaran bentuk/ tepi lesi pada temuan USG tumor payudara ganas yang disampaikan dalam hasil penelitian juga berbeda dengan apa yang dikemukakan oleh Zhou $\mathrm{Y}^{2}$ dalam penelitiannya, yang menyebutkan bahwa pada umumnya tumor payudara ganas dominan memiliki batas/ tepi lesi yang ireguler.

Hasil yang berbeda juga dapa dilihat pada karakteristik gambaran batas lesi tumor payudara ganas. Hasil yang dikemukakan dalam penelitian ini berbeda dengan hasil penelitian yang diungkapkan oleh Karan, dkk ${ }^{8}$ yang menyebutkan bahwa pada tumor payudara ganas akan tampak batas lesi yang tidak tegas lebih dominan pada temuan ultrasonografi.

Namun, ada pula beberapa hasil penelitian yang serupa dengan apa yang disajikan dalam penelitian ini. Terkait karakteristik gambaran kalsifikasi pada tumor payudara ganas, penelitian yang dilakukan oleh Susan, dkk ${ }^{9}$ menyatakan bahwa adanya teman kalsifikasi tumor payudara sangat umum terjadi dan berkembang secara alami, namun kadang-kadang menjadi tanda awal dari keganasan. Penelitian yang dilakukan oleh Willett A, dkk ${ }^{10}$ juga memiliki hasil serupa dengan penelitian ini. Penelitian tersebut menyatakan bahwa tidak semua proses keganasan menimbulkan adanya retraksi papilla, namun bila tampak adanya retraksi papilla dapat dipastikan bahwa itu merupakan suatu proses keganasan.

\section{SIMPULAN}

Karakteristik gambaran temuan dari penggunaan ultrasonografi sebagai skrining kasus tumor payudara ganas dalam penelitian ini mampu menilai beberapa temuan yang umum terjadi pada pasien dengan tumor payudara ganas. Namun, hasil dari penelitian ini tidak sepenuhnya sejalan dengan penelitian serupa yang telah dilakukan sebelumnya.

Total sampel yang digunakan dalam penelitian ini terkait data karakteristik masih sangat terbatas, sehingga perlu dilakukan penelitian lebih lanjutan, atau penelitian serupa dengan jumlah sampel yang lebih besar, lokasi penelitian yang lebih luas, serta variabel-variabel lain yang dapat diteliti sehingga dapat memperkecil bias pada penelitian. Dalam penelitian selanjutnya juga diharapkan dapat menngunakan desain penelitian lain, yaitu dengan menggunakan data primer seperti halnya menggunakan kuesioner atau teknik wawancara. Dalam penggunaan rekam medis sebagai sumber data penelitian sebaiknya melampirkan data pasien yang lebih lengkap sehingga pada penelitian selanjutnya tidak terdapat data yang tidak diketahui.

\section{ETHICAL CLEARANCE}

Penelitian ini sudah mendatap persetujuan dari Komisi Etik Penelitian (KEP) Fakultas Kedokteran Universitas Udayana/Rumah Sakit Umum Pusat Sanglah Denpasar, Nomor 1747/UN.14.2/ Litbang/2016.

\section{KONFLIK KEPENTINGAN}

Penulis menyatakan tidak terdapat suatu konflik kepentingan terhadap publikasi dari artikel ini. 


\section{PENDANAAN}

Penelitian ini tidak mendapatkan suatu pendanaan yang diberikan oleh pemerintah ataupun lembaga swasta lainnya.

\section{KONTRIBUSI PENULIS}

Konsep penelitian: I Kadek Riyandi Pranadiva Mardana, Elysanti Dwi Martadiani, Firman Parulian Sitanggang. Pengumpulan data, input data dan pengolahan data: I Kadek Riyandi Pranadiva Mardana. Penyusunan naskah Penelitian: I Kadek Riyandi Pranadiva Mardana.

\section{DAFTAR PUSTAKA}

1. Ana K. Panduan Lengkap Kesehatan Wanita. Gala Ilmu Semesta.2007.

2. Zhou Y. Ultrasound diagnosis of breast cancer. American Scientific Publishers. 2013;3:1-14.

3. Fadjari H. Pendekatan Diagnosis Benjolan di Payudara. CDK. 2012;39(4):308-309.
4. Ali W, Day P, Weir R. Risk Factors for Breast Cancer in Woman. New Zealand: NZHTA REPORT. 2007;10(2):97.

5. American Cancer Society [Internet]. Breast Cancer Prevention and Early Detection. Accessed at www.cancer. org/Cancer/BreastCancer/DetailedGuide/index on January 11. 2015.

6. Chan V, Perlas A. Basics of Ultrasonografi Imaging. Canada: Atlas of Ultrasound-Guided Procedures in Interventional Pain Management.2011. p.1-17.

7. Ramli M. Update Breast Cancer Management Diagnotic And Treatment. Indonesia: Majalah Kedokteran Andalas.2015;38(1):28-53

8. Bolat FA, Karan B, Pourbagher A. Unusual Malignant Breast Lesions: Imaging-Pathological Correlations. Turkey: Turkish Society of Radiology.2012;18(3):270-276.

9. Susan G[Internet]. Breast Calsifications. Accessed at www. komen.org/question on Januari 17.2016.

10. Hughes J, Lee M, Loftus R, Willet A. Best Practice Diagnostic Guidelines for Patients Presenting with Breast Symptoms. England: Department of Health. 2011.p.1-60.

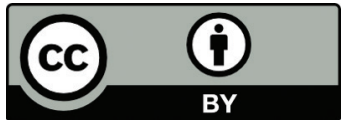

This work is licensed under a Creative Commons Attribution 